\title{
Біомеханічні аспекти раціоналізації процесу навчання рухів у процесі технічної підготовки спортсменів
}

\section{Володимир Гамалій}

Національний університет фізичного виховання і спорту України, Київ, Україна

Анотація. Стаття присвячена актуальній на сьогодні проблемі - підвищення ефективності тренувального процесу і технічної підготовки завдяки використанню теоретичних і практичних напрацювань і можливостей спортивної біомеханіки, впровадженню біомеханічних технологій, розширенню ролі дидактичної компоненти тренувального процесу як основного засобу формування дієвої дидактичної платформи вдосконалення рухової діяльності людини під час занять спортом. Мета. Аналіз біомеханічних аспектів раціоналізації процесу навчання рухів у процесі технічної підготовки спортсменів. Методи. Теоретичний аналіз та узагальнення даних спеціальної науково-методичної літератури, мережі Інтернет та практичного досвіду. Результати. Дидактичний процес спортивного тренування, спрямований на навчання нових рухових дій і удосконалення вже опанованих, постійно змінюється і потребує від педагога-тренера нових методичних підходів і творчого осмислення його змістовності. Висвітлені в статті положення про раціоналізацію процесу навчання рухів у процесі технічної підготовки спортсменів підтверджуються практичним втіленням їх у тренувальний процес спортсменів різної кваліфікації. Автор приходить до висновку, що теоретичну базу технічної підготовки спортсменів у різних видах спорту формують основні положення спортивної біомеханіки, одним із напрямів якої є педагогічна складова раціоналізації процесу технічної підготовки, що дозволяє підвищувати ефективність спортивної практики шляхом аналізу рухової активності і її конструктивним синтезом, обгрунтуванням спортивної техніки, її конструюванням, пошуком шляхів удосконалення, знаходженням і осмисленням причин рухових помилок і есективних шляхів боротьби з ними, в тому числі шляхів і прийомів просілактики їх появи.

Ключові слова: біомеханіка спорту, технічна підготовка, раціоналізація, навчання рухів, дидактика.

\section{Volodymyr Hamalii}

\section{BIOMECHANICAL ASPECTS OF RATIONALIZATION OF THE MOVEMENT LEARNING PROCESS DURING TECHNICAL TRAINING OF ATHLETES}

Abstract. The article is devoted to the current problem - increasing the efficiency of the training process and technical training through the use of theoretical and practical developments and opportunities of sports biomechanics, the introduction of biomechanical technologies, expansion of the role of didactic component of the training process as the major means of formation of efficient didactic platform for improving human motor activity during sports engagement.

Objective. Analysis of biomechanical aspects of rationalization of the process of learning movements in the process of technical training of athletes. Methods. Theoretical analysis and generalization of data from special scientific and methodological literature, the Internet and practical experience. Results. The didactic process of sports training aimed at learning new motor actions and improving the already mastered, is constantly changing and requires from the teacher-coach new methodological approaches and creative understanding of its content. The provisions highlighted in the article on the rationalization of the process of learning movements during technical training of athletes are confirmed by their practical implementation in the training process of athletes of different qualifications. The author concludes that the theoretical basis of technical training of athletes in various sports events is formed by the basic provisions of sports biomechanics, one of the directions of which is the pedagogical component of rationalizing the process of technical training, which allows to increase sports practice efficiency through motor action analysis and its constructive synthesis, sunstantiation sports technique, its construction, finding ways to improve, find and understand the causes of motor errors and effective ways to avoid them, including ways and means of their occurrence prevention.

Keywords: sports biomechanics, technical training, rationalization, motion learning, didactics.

Hamalii V. Biomechanical aspects of rationalization of the movement learning process during technical training of athletes. Theory and Methods of Physical education and sports. 2020; 2: 36-41

DOI: 10.32652/tmfvs.2020.2.36-41
Гамалій В. Біомеханічні аспекти раціоналізації процесу навчання рухів у процесі технічної підготовки спортсменів. Теорія і методика фрізичного виховання і спорту. 2020; 2: 36-41 DOI: 10.32652/tmfvs.2020.2.36-41
Вступ. В останні роки спортивна біомеханіка досягла великих успіхів. Біомеханічні технології дають можливість фахівцям не тільки проводити аналіз фрундаментальних закономірностей процесу сучасного розвитку спорту, а й творчо осмислювати і прогнозувати його майбутні тенденції та перспективи [12, 15, 28, 33]. Дослідження, які ще багато років тому здавалися немислимими, сьогодні можливі на основі новітніх розробок у сфрері вимірювальної техніки. Сучасні оптико-електронні методи реєстрації й аналізу рухів спортсмена досягли певної досконалості і за кваліфікованого використання забезпечують вирішення всього спектра проблем, що стоять перед тренером у процесі здійснення технічної підготовки $[4,6]$. Це дозволяє працювати над новими питаннями, перевіряти старі парадигми і розробляти абсолютно нові дослідницькі підходи.

Крім того, істотно змінилися сфери досліджень спортивної біомеханіки. Якщо в 1970-1980-ті роки біомеханіка спорту передувала біомеханіці спортивних рухів як інструмент їх аналізу, то в останні десятиліття все більше розвивається і фрундаментальна, орієнтована на всебічні дослідження, біомеханіка процесів, які певною мірою сприяють досягненню бажаного спортивного результату. Існує цілий ряд публікацій на спортивну тематику, в яких досить обґрунтовано висвітлені теми, що не мають прямого практичного значення для розширення спортивного досвіду [19, 20, 23, 24, 29], потребують більш поглиблених знань для трансфрормації їх змісту на вирішення конкретних проблем підготовки спортсменів.

Сучасні дослідження в галузі спорту у наших зарубіжних партнерів стосуються найчастіше дуже вузьких питань і мають суто науковий фунндаментальний характер, що стосується медицини, морфології, генетики. 
Нині проводиться інтенсивна робота з комп'ютерного моделювання та моделювання повсякденних послідовностей рухів людини $[2,10,11,13,16,30$, 34]. Біомеханічні проблеми вирішуються так, що миттєвого спортивного результату за матеріалом дослідження отримати практично неможливо. Це $є$ серйозною перепоною для спортивних спеціалістів, а тому важливо на основі знань біомеханізмів основних груп рухів створити біосимптоматику, що допоможе тренеру розуміти помилки і за можливості їх коригувати [12].

Змінилися і вимоги до спортивної біомеханіки, а отже, і до фрахівців, які працюють у цій галузі. у сучасній спортивній біомеханіці потрібні спеціалісти не тільки 3 специфічними спортивними компетенціями, багато питань можуть бути вирішені тільки в міждисциплінарних дослідницьких групах, де кожен член такої, як очікується, буде володіти базовими знаннями з усіх задіяних дисциплін. Це також пояснює, чому біологічнофрізіологічні знання можуть бути настільки ж важливі сьогодні, як і інженерно-науково-срізичні. Як свідчить практика, найчастіше тісна співпраця між вченими-спортсменами і лікарями-травматологами або хірургами-ортопедами не може бути плідною для всіх учасників без глибокого розуміння анатомічних, фізіологічних, психологічних основ і етіологічних деталей $[17,18]$. Спортивні рухові дії $€$ об'єктом дослідження не тільки біомеханіки, а й морфології, фрізіології, психології, педагогіки та інших наук.

Особливу увагу необхідно звернути на педагогічну складову тренувального процесу і технічної підготовки, яка, на думку деяких учених [14], значною мірою випадає із загальної теорії управління рухами. Однак у спорті саме педагогічна установка на виконання руху $є$ найважливішим елементом, що дозволяє спортсменові реалізувати рухову дію у всій складній взаємодії раціонально спланованих механічних, біологічних і психологічних компонентів. Педагогічні методи, що спираються на словесні й образні характеристики рухів, дозво- ляють ссрормувати у спортсмена образ руху і відповідну цільову установку [27]. На жаль, цей аспект зазвичай випадає з поля зору фахівців, які віддають перевагу біомеханічним, фрізіологічним і психологічним сторонами управління рухами. У той самий час спортивна педагогіка, передова практика підготовки спортсменів в останні десятиліття сфрормували великий обсяг емпіричного матеріалу і його узагальнень, пов'язаних з формуванням складних рухових навичок у всьому спектрі взаємодій провідного і фронового рівнів, єдності внутрішніх і зовнішніх характеристик i, що найскладніше, реалізацією цих навичок під час постійної зміни внутрішнього середовища організму (включаючи стан глибокого стомлення), варіативності, динамічності і мінливості зовнішнього середовища [14].

Відмінність педагогіки спорту від інших педагогічних наук полягає в тому, що вона встановлює свої принципи і правила, визначає засоби, методи і умови вирішення завдань [4, 26 , 31]. Ґрунтуючись головним чином на закономірностях оволодіння руховими діями, педагогіка спорту повинна сприяти не тільки розвитку функцій організму і рухових здібностей, а головне - фрормувати дієву дидактичну платформу вдосконалення рухової діяльності людини під час занять спорTOM.

Мета дослідження - аналіз біомеханічних аспектів раціоналізації процесу навчання рухів у процесі технічної підготовки спортсменів.

Методи дослідженя: теоретичний аналіз та узагальнення даних спеціальної науково-методичної літератури, мержі Інтернет, практичного досвіду.

Результати дослідження та їх обговорення. Попередньо зробимо зауваження, що дані, які наведені в статті, $є$ аналітичним оглядом з критичним і фррагментарним обрисом кола проблем. Дидактичний процес спортивного тренування, спрямований на навчання нових рухових дій і удосконалення вже опанованих, постійно змінюється на принципах раціоналізації і потребує від педагога-тренера нових методичних підходів і творчого осмислення його змістовності [21, 26, 31]. Теоретичний аналіз спеціальної науково-методичної літератури, даних мережі Інтернет та узагальнення практичного досвіду дозволили визначити нові можливості раціоналізації навчання рухів, які доцільно розглянути щонайменше в трьох основних аспектах і це при тому, що дійсне коло проблемних питань із задекларованої тематики значно ширший.

Перший аспект полягає в безперервності процесу освоєння рухових умінь, незважаючи на те що він поділяється на два етапи: навчання рухів і вдосконалення в них $[4,15]$. Навчання нових рухів, що вдосконалюються, проходить і на найвищих рівнях спортивно-технічної майстерності, але лише 3 однією відмінністю від навчання на початкових етапах, а саме - здійснюється на більшому арсеналі рухових умінь і навичок, якими вже володіє спортсмен. Саме це і є домінуючим фактором, який позитивно впливає на терміни процесу навчання і його якість. За умови, що рухова дія, яку запропоновано для вивчення, має елементи знайомих спортсмену рухів, освоєних у повсякденній руховій практиці або у специфічних умовах спортивного тренування, процес фрормування нового уміння а потім і навички проходить значно швидше [32]. 3 огляду на це, професійна придатність тренера полягає в його умінні запропонувати своєму учню такий алгоритм навчання нових рухів, який базується на послідовному нашаруванні вже освоєних ним фррагментів рухів з метою отримання на кінцевому етапі навчання якісно нового рухового уміння, що і стане елементом удосконалення всієї рухової дії.

Другий аспект стосується нових можливостей навчання і базується на положеннях про залежність зовнішніх характеристик рухів від їх внутрішнього структурного змісту $[6,15]$. Це $є$ підтвердженням того, що як саме навчання рухів, так і вдосконалення в них значною мірою залежать від уміння координувати своє м'язове напруження [5]. Слід зазначити, що прагнення до досягнення певних результатів забезпечується, насамперед, узгодженням рівнів м'язової координа- 
ції безпосередньо в ході розгортання рухів [3] з одночасним освоєнням умінь досягати оптимальних рівнів внутрішньом'язової координації у вирішальні моменти. Нервово-м'язова координація виступає системотвірним фактором відносно активних зусиль і рухів людини і $є$ непрямим відображенням впорядкованості 30внішніх і внутрішніх відносно організму сил, що виникають під час вирішення рухового завдання [3, 5, 31]. В умовах спортивної та будь-якої іншої рухової діяльності людини координують не стільки рухи, скільки зусилля, що викликають і регулюють рухи [3, 9]. Якщо розглядати викладене вище в контексті техніки рухової дії як способу організації внутрішніх та зовнішніх сил відносно тіла людини у функціональну систему на основі мети дії, то м'язовій координації в цьому процесі належить провідна роль [7].

Третій аспект, що стосується можливостей раціоналізації процесу навчання рухів, полягає в тому, що раціональним він може стати лише при визначенні кінцевих цілей, виражених через конкретний спортивний результат. Висування результату як системотвірного фактора для підбору засобів навчання приводить до висновку, що найбільш доцільної організації засобів навчання можна досягти при спеціальному створенні умов тренування, максимально наближених до реалізації основної фізичної вправи у змагальних умовах $[8,15,26]$.

Положення про безперервність навчання змушує шукати можливості навчати всіх спортсменів більш досконалого виконання рухів, навіть тих, які володіють вищою спортивнотехнічною майстерністю. При цьому слід виходити із реального факту, що максимальна реалізація потенціалу рухових можливостей спортсмена через рухи, які він виконує, принципово недосяжна. Однак завжди є резерви зростання результативності, з чого випливає необхідність навчити спорсмена самому знаходити ці резерви [15].

Рівень вищої майстерності $€$ тонким мінливим налаштуванням рухових механізмів, а також механізмів забезпечення психіки. Нестійкість цих налаштувань поки що мало береть- ся до уваги, оскільки тривалі спостереження за проявами вищої технічної майстерності здійснені лише за умов наявності складних тренажернодослідних стендів, які мають лише кілька лабораторій.

Дискусія. Опановуючи техніку фрізичних вправ у процесі тренування спортсмени беруть участь в активному пізнанні зовнішнього світу. Це здійснюється через сприйняття 30внішніх та внутрішніх взаємодій власного тіла з об'єктами середовища, у котрому відбувається рух. Загальна картина цієї взаємодії відображає закономірності організації біодинамічно структури кожної фрізичної вправи. У випадках, коли йдеться про пізнання рухів (опанування у процесі тренування), особливо складно забезпечити завдання адекватного відображення спортсменом того чи іншого руху-зразка (об'єкта пізнання). Будьякий рух є багатоструктурним. Охопити його одним, навіть досвідченим поглядом, неможливо. Тренер має допомогти спортсменові у цьому шляхом так званого активного вилучення найсуттєвішої інформації про рухи і виключенням другорядної.

Дидактичні завдання освоєння змагальних рухових дій підводять до проблем наповнення рухів внутрішнім змістом. Це стосується сфери дії одного з корінних протиріч, основна суть якого полягає в тому, що спрямованість навчання, хоча й орієнтована на формування внутрішнього змісту рухів, реалізується на основі спроб наслідування їх еталонним зовнішнім формам, що ставляться вчителем або тренером як зразок. Рухові уявлення спортсмена не обмежуються наочним образом руху, а охоплюють широку гаму модальних компонентів, включаючи різноманітні відчуття, не рахуючи більш абстрагованої інформації, пов'язаної з осмисленням рухової дії, її структури і техніки [4]. М. О. Бернштейн зазначав 3 цього приводу: «Звичайно, раціональним і правильно поставленим буде таке тренування, при якому з витратою найменшо роботи буде поєднуватися найбільша, добре продумана різноманітність відчуттів і будуть створені найкращі умови, щоб осмислено запам'ятати і за- своїти всі ці відчуття» [1]. Розуміння цього моменту дуже важливе, тому що від нього залежить методика підбору найбільш ефективних вправ, в яких повинні бути реалізовані саме інформативні компоненти рухових уявлень, що найбільш точно і повно віддзеркалюють структурно-технічні властивості конкретної рухової дії.

Усвідомленню цього протиріччя перешкоджають не тільки укорінена практика навчання на основі наслідування, а й відсутність у спортивного педагога інструментальних засобів для контролю за правильністю фрормування рухів. Неможливість контролю внутрішнього змісту рухів закріпила у свідомості і практиці навчальні схеми, в яких рухові дії освоювалися на основі їх спрощення і розчленування на елементи, що виправдовувалося бажанням дотримуватись рекомендацій, згідно з якими шлях «від простого до складного» цілком логічний [22, 25]. Однак не менш важливим положенням під час навчання фрізичних вправ, а в деяких випадках і провідним, $€$ «від головного до другорядного» $[4,8]$.

3 цього приводу показовим є приклад, який наведено в одній з публікацій [15]. Традиційна схема рекомендацій методичних прийомів початкового навчання метання диска виявляє неузгодженість цих положень. За цією схемою пропонують дітям і підліткам виконувати підкидання і кидки полегшеного снаряда. Однак це завдання не таке просте. Найважче - домогтися від учнів виконання кидка за рахунок зусиль великих м'язів тулуба і ніг. Кинути полегшений диск рухом однієї руки дуже легко, що зазвичай і здійснюється, створюючи передумови для закріплення помилки.

Якщо керуватися положенням «від головного до другорядного», то головним $є$ вміння створити правильну координацію зусиль великих м'язових груп, що забезпечують досить високий результат. Початківцю не можна давати легкий диск, щоб не привчити його виконувати спрощений варіант рухів, що реалізується на основі використання лише другорядних, до того ж ще і швидкоскоротних м'язів. 
Щоб запобігти можливості порушення м'язової координації навчання рухів, метання слід починати з вправи 3 відносно важким мішком 3 піском. Учня слід поставити у вихідне положення, при якому виконати рухове завдання він зміг би тільки правильним способом. Вихідним $є$ положення, коли учень повинен відтворювати рухи фрінального зусилля метання, витягуючи поставлений мішок 3 піском не правою, а лівою рукою. Права рука (що метає) лише підтримує мішок, а розкручуючі рухи ніг і тулуба забезпечують кидок мішка зусиллями великих м'язів. При цьому вільна права рука весь час відстає від випереджальних рухів ніг і тулуба. Виконання подібної вправи зусиллями великих м'язів при забороні на несвоєчасну або зайву активність швидкоскоротних м'язів метальної руки вказує на можливості виходу зі своєрідних «дидактичних тупиків», коли головні завдання навчання можуть відступити на другий план внаслідок недостатньо продуманого підбору навчальних прийомів.

Подальшого розвитку методика формування внутрішнього змісту рухів 3 акцентом на провідний елемент техніки набула в дослідженнях [7], в яких спортивний результат виступав як системотвірний фактор для підбору засобів навчання і створення умов тренування, максимально наближених до реалізації основної фрізичної вправи в змагальних умовах. Формування раціональної структури рухів здійснювалось завдяки використанню різних систем обтяжень. У метанні молота, як виявлено у ході проведених досліджень, одним із базових моментів $є$ узгодженість руху осі таза відносно осі плечей атлета. Керуючись цим положенням, було розроблено технологію вдосконалення технічної майстерності метальників молота в умовах використання різноманітних систем обтяжень, яка включає певні вимоги до її застосування на практиці (може застосовуватися в різних видах спорту): 1) попередній біомеханічний аналіз техніки рухової дії, під час виконання якої буде застосовуватись зміна мас-інерційних показників тіла атлета; 2) визначення недо- ліків у техніці змагальної вправи; 3) визначення співвідношення характеру зміни обраних показників з дискримінативними характеристиками, що визначають результат у виконанні рухової дії із урахуванням індивідуальних фракторів (зріст, маса, пропорції тіла). Такий підхід забезпечує уникнення концентрації уваги на другорядних фракторах і визначає зміст, фрорму, завдання та модель виконання рухової дії під час застосування технології зміни мас-інерційних показників біоланок тіла атлета; 4) розрахунок маси та положення обтяження на тілі спортсмена із обов'язковою апробацією його під час виконання змагальної дії; 5) під час застосування на практиці певної системи обтяжень необхідно віддавати перевагу мінімізації кількості повторень виконання вправи та збільшенню спроб атлета відтворення необхідної моделі рухової дії у звичайних умовах за рахунок підвищення активного контролю спортсмена над збереженням ссрормованого образу рухової дії; 6) застосування протягом тривалого часу обраної системи обтяжень доцільне в підготовчому періоді, коли відбувається підвищення рівня силової підготовки, яка спричиняє можливість порушення координаційної структури рухів атлета. Також цей підхід можливий під час перебудови укоріненого варіанту виконання рухової дії; 7) оптимальною масою обтяження на початку його застосування є 5 \% маси ланки тіла атлета, на якій фріксується обтяження; 8) найбільш ефективним $€$ розташування обтяжень у зоні центрів тяжіння ланок тіла атлета, що не порушує вектор природної їх гравітації. При розташуванні обтяжень в інших зонах тіла атлета необхідно співвіднести зміну напрямку руху точки із заданою за рахунок виникнення та зростання інерційних сил під час виконання рухової дії.

Після впровадження протягом річного циклу в практику підготовки кваліфікованих метальників молота технології застосування різноманітних систем обтяжень у процесі удосконалення їх технічної майстерності було отримано дані, що вказують на зміну не тільки кількісних значень кінематичних характеристик, а й перебудову характеру їх зміни, що наблизився до структури кидка на 80 м.

Розроблена технологія та виявлені дискримінативні ознаки техніки кидка молота атлетами високої кваліфікації дозволяють тренеру та атлету цілеспрямовано формувати модель виконання рухової дії та успішно реалізовувати її на практиці. Даний підхід вирішує головне завдання процесу навчання та вдосконалення спортивної техніки - ефективне управління руховою системою спортсмена шляхом диференційованої корекції силових взаємодій, які визначають просторові, часові та просторово-часові характеристики руху, що і становить суть удосконалення техніки рухової дії і раціоналізації технічної підготовки спортсменів.

Навчання вправ - конструктивний процес, який завжди передбачає пошук найкращого вирішення рухових завдань, що послідовно висуваються перед виконавцем і представлених у срормі рухової мети з оголошеною установкою на бажаний характер його виконання. Практично неминучий результат такої роботи - подолання труднощів, проблемних ситуацій i, як наслідок, помилок виконання. Для того щоб успішно вирішувати названі проблеми удосконалення технічної майстерності спортсменів високої кваліфікації, слід підходити до них комплексно, системно, розглядаючи у єдності з усіма іншими актуальними питаннями розвитку олімпійського та професійного спорту. Перспективи застосування біомеханічних технологій показують, що в умовах спеціальної підготовки нині для спортсменів можна створити таку динамічну систему удосконалення технічної майстерності, котра дала б змогу добре виступати на усіх найбільших змаганнях.

Висновки. Теоретичну базу технічної підготовки спортсменів у різних видах спорту становлять основні положення спортивної біомеханіки, в рамках якої проводять дослідження, обґрунтовують закономірності та критерії есрективності техніки, досліджують досягнення спортивної практики, встановлюють принципи і методики моделювання раціональних зразків 
техніки, виявляють біомеханічні причини рухових помилок і можливості їх подолання. Крім того, спортивна біомеханіка розглядає енертичну сторону забезпечення рухової функції. Поряд 3 цим вона як навчально-наукова дисципліна виступає і як педагогічний засіб раціоналізації процесу технічної підготовки спортсменів, що дозволяє підвищувати ерективність спортивної практики через аналіз рухової активності і її конструктивний синтез, обґрунтування спортивної техніки, її конструювання, знаходження шляхів її вдосконалення, осмислення причин рухових помилок і ефективних шляхів боротьби з ними, в тому числі шляхів і прийомів профрілактики їх появи.

Перспективи подальших досліджень передбачають розгляд засобів і методів раціоналізації технічної підготовки спортсменів в окремих видах спорту на основі застосування біомеханічних технологій.

Конфлікт інтересів. Автор заявляє, що відсутній будь-який конфрлікт інтересів.

\section{ЛІТЕРАТУРА}

1. Бернштейн АН. Живое движение. Москва: Знание, 1964. 47 с.

2. Васильева Л. Прикладная кинезиология Восстановление тонуса и функций скелетных мпышц. Форс, 2019. 304 с.

3. Верхошанский Ю. Организация сложных двигательных действий в спорте. Наука в олимпийском спорте. 1998; 3: 8-22.

4. Гавердовский ЮК. Обучение спортивным упражнениям. Биомеханика. Методология. Ди дактика. Москва: Физкультура и спорт, 2007 911c.

5. Гамалий ВВ. Координация мышечных напряжений как составляющая техники двигательных действий человека, Наука в олимпийском спорте. 2008; 1: 102-105.

6. Гамалий ВВ. Теоретико-методические основы моделирования техники двигательных действий в спорте. Киев: Полиграфсервис 2013. 300 c.

7. Гамалий ВВ. Проблемы и перспективы совершенствования технической подготовки спортсменов. Наука в олимпийском спорте. 2015; 2: 67-72.

8. Гамалий ВВ, Островский МВ. Современная технология использования различных отягощений на теле спортсмена в технической подготовке квалифицированных метателей молота, Наука в олимпийском спорте. 2011; 1-2 87-96.

9. Гамалий В, Ланка Я, Литвиненко Ю, Шевчук Е. Теоретико-практические аспекты использования упругих свойств сухожильномышечных структур человека в организации перемещающих движений в спорте, Спортивний вісник Придніпров'я. 2017; 2: 200-207.
10. Даймон Т. Анатомия тела в движении. Попури, 2020. 224 с.

11. Закиров ВР. Компьютерное моделирование в физической культуре и спорте. В: При кладная электродинамика, фотоника и живые системы. Казань, 2018.

12. Иванова ГП. Развитие биомеханики как основа успеха в олимпийском спорте. Ученые записки, 2010; 11(69).

13. Моссэ Ирма Молекулярно-генетические технологии в спорте высших достижений. Наука в олимпийском спорте. 2015; 1: 43-51.

14. Платонов ВН. Двигательные качества и ффизическая подготовка спорсменов. Киев: Олимпийская лит., 2017. 656 с.

15. Ратов ИП, Попов ГИ, Логинов АА, Шмонин БВ. Биомеханические технологии подготовки спорсменов. Москва: Физкультура и спорт 2007. 127 C.

16. Сергієнко ЛП. Спортивна генетика. Богдан, 2014. 914 с.

17. Соломон Луи, Уорик Дэвид, Ньягам Селвадураи. Ортопедия и травматология по Эпли. Руководство. В 3 ч. Ч 3: Повреждения костей и суставов. ВАМ, 2016. 314 с.

18. Уолкер Бред. Анатомия спортивных травм. Поппури, 2016. 272 с.

19. Eckstein F, Hudelmaier M. and Putz R. The effects of exercise on human articular cartilage Journal of Anatomy, 2006; 208: 491-512.

20. French D. Adaptations to anaerobic training programs. In: G.G. Haff and N.T. Triplett, eds. Essentials of strength training and conditioning 4th ed. Champaign, IL: Human Kinetics, 2016. 87-114.

21. 15 Albert Muller Erich. Handbuch Sportbiomechanik. Schorndorf: Hofmann-Verlag, 2009. 510

22. Hape RN. Pedagogical approach to Sport Education [WWW] Available from: https://www. brianmac.co.uk/articles/article332.htm

23. Herda TJ and Cramer JT. Bioenerge tics of exer- y cise and training. In: G.G. Haff and N.T. Triplett, eds., Essentials of strength training and conditioning, 4th ed. Champaign, IL: Human Kinetics, 2016. 43-64

24. McArdle WD, Katch FI and Katch VI. Physiology Exercise. Philadelphia: Lea and Febiger, 2014.

25. Nicolette HMJ. Schipper-van Veldhoven. Sports and physical education from a pedagogical perspective: a golden opportunity, 2017. ISBN 978 9071902239

26. Laputin AN. Didaktik biomechanics: problems and solutions. Ukrainian State Univ. of Phys. Education and Sports. Budapest, 1994. 49.

27. Schnabel G. Dewegungsregulation fls Informationsonorganisation. In: Trainingswis styschaft? 1 st ed. Berlin: Sportverlag, 1994 60-92.

28. Schnur Axel, Schwameder Hermann. Praxisorientiete Biomechanik im Sportunterricht Vom Tun zum Verstehen. Schorndorf: HofmannVerlag, 2016. $216 \mathrm{~s}$

29. Swank A. and Sharp C. Adaptations to aerobic endurance training programs. In: G.G. Haff and N.T. Triplett, eds., Essentials of strength training and conditioning, 4th ed. Champaign, IL: Human Kinetics, 2016. 115-134.

30. W. Myers Thomas. Anatomy Trains: Myofascial Meridians for Manual Therapists and Movement Professionals, 4th Edition. 2014. ISBN-13 978-0702078132.

31. Ward P. The role of content knowledge in conceptions of teaching effectiveness in physical education. Research Quarterly for Exercise and Sport. 2013; 84(4): 431-440.
32. Wiek D. Biomechanische Grundlagen sportlicher Bewegungen. Balingen Potsdam: Spitta Verlag, 2004

33. Wiek D. Biomechanik im Sport. Lehrbuch Biomechanische Grundlagen sportlicher Bewegungen. Balingen Potsdam: Spitta Verlag, 2013. $306 \mathrm{~s}$

34. Zatsiorsky V, Prilutsky B. Biomechanics of Skeletal Muscles 1st edition. Hardcover, 2012 January 1. 1600.

\section{LITERATURE}

1. Bernstein AN. Live motion. Moscow: Znaniye, $1964.47 p$.

2. Vasilyeva L. Applied kinesiology. Tone and skeletal muscle function recovery. Fors, 2019. $304 \mathrm{p}$.

3. Verkhoshansky Y. Complex motor action organization in sport. Nauka v Olimpiyskom sporte. 1998; 3: 8-22.

4. Gaverdovsky YK. Teaching sports exercises. Biomechanics. Methodology. Didactics. Moscow: Fizkultura i sport, 2007. 911p.

5. Gamaliy VV. Coordination of muscular tensions as the constituent of human motor action technique, Nauka v Olimpiyskom sporte. 2008; 1 : 102-105.

6. Gamaliy VV. Theoretico-methodical bases of motor action technique modeling in sport. Kiev: Poligrafservis, 2013. 300 p.

7. Gamaliy VV. Problems and prospects of improving the technical training of athletes. Nauka v Olimpiyskom sporte. 2015; 2: 67-72.

8. Gamaliy VV, Ostrovsky MV. Modern technology of using various weights on the body of an athlete in the technical training of qualified hammer throwers, Nauka v Olimpiyskom sporte. 2011; 1-2: 87-96.

9. Gamaliy V, Lanka $Y$, Litvinenko $Y$, Shevchuk $E$. Theoretico-practical aspects of using elastic properties of human tendon and muscle structures in organizing displacement motions in sport, Sportyvnyi visnyk Prydniprovia. 2017; 2: 200-207.

10. Dimon T. Human anatomy in motion. Popuri, 2020. 224 p.

11. Zakirov VR. Computer modeling in physical culture and sport. In: Applied electrodynamics, photonics and living systems. Kazan, 2018.

12. Ivanova GP. Biomechanics development as the basis for success in the Olympic sports. Uchenye zapiski, 2010; 11(69).

13. Mosse Irma. Molecular genetic technologies in elite sport. Nauka v Olimpiyskom sporte. 2015; 1: 43-51

14. Platonov VN. Motor qualities and physical preparation of athletes. Kiev: Olimpiyskaya literatura, 2017. $656 \mathrm{p}$

15. Ratov IP, Popov GI, Loginov AA, Shmonin BV. Biomechanical technologies of athlete preparation. Moscow: Fizkultura i sport, 2007. $127 \mathrm{c}$.

16. Serhiienko LP. Sports genetics. Bohdan, 2014. 914 p.

17. Solomon Louis, Warwick David, Nyagam Selvadurai. Epley Orthopedics and Traumatology. Guide. In 3 p. P 3: Bone and joint damage. BAM, 2016. 314 p.

18. Walker Brad. Anatomy of sports injuries. Poppuri, 2016. 272 p.

19. Eckstein F, Hudelmaier M. and Putz R. The effects of exercise on human articular cartilage. Journal of Anatomy, 2006; 208: 491-512.

20. French D. Adaptations to anaerobic training programs. In: G.G. Haff and N.T. Triplett, eds., Essentials of strength training and conditioning, 
4th ed. Champaign, IL: Human Kinetics, 2016. $87-114$.

21. 15 Albert Muller Erich. Handbuch Sportbiomechanik. Schorndorf: Hofmann-Verlag, 2009. 510.

22. Hape RN. Pedagogical approach to Sport Education [WWW] Available from: https://www. brianmac.co.uk/articles/article332.htm

23. Herda TJ and Cramer JT. Bioenergetics of exer- $y$ cise and training. In: G.G. Haff and N.T. Triplett, eds., Essentials of strength training and conditioning, 4th ed. Champaign, IL: Human Kinetics, 2016. 43-64.

24. McArdle WD, Katch Fl and Katch VI. Physiology Exercise. Philadelphia: Lea and Febiger 2014.

25. Nicolette HMJ. Schipper-van Veldhoven Sports and physical education from a pedagogical perspective: a golden opportunity, 2017. ISBN 978 9071902239.

26. Laputin AN. Didaktik biomechanics: problems and solutions. Ukrainian State Univ. of Phys. Education and Sports. Budapest, 1994. 49.

27. Schnabel G. Dewegungsregulation fls Informationsonorganisation. In: Trainingswisstyschaft? 1 st ed. Berlin: Sportverlag, 1994. 60-92.
28. Schnur Axel, Schwameder Hermann. Praxisorientiete Biomechanik im Sportunterricht Vom Tun zum Verstehen. Schorndorf: HofmannVerlag, 2016. $216 \mathrm{~s}$

29. Swank A. and Sharp C. Adaptations to aerobic endurance training programs. In: G.G. Haff and N.T. Triplett, eds., Essentials of strength training and conditioning, 4th ed. Champaign, IL: Human Kinetics, 2016. 115-134.

30. W. Myers Thomas. Anatomy Trains: Myofascial Meridians for Manual Therapists and Movement Professionals, 4th Edition. 2014. ISBN-13: 978-0702078132.

31. Ward P. The role of content knowledge in conceptions of teaching effectiveness in physical education. Research Quarterly for Exercise and Sport. 2013; 84(4): 431-440.

32. Wiek D. Biomechanische Grundlagen sportlicher Bewegungen. Balingen Potsdam: Spitta Verlag, 2004

33. Wiek D. Biomechanik im Sport. Lehrbuch Biomechanische Grundlagen sportlicher Bewegungen. Balingen Potsdam: Spitta Verlag, 2013. $306 \mathrm{~s}$.

34. Zatsiorsky V, Prilutsky B. Biomechanics of Skeletal Muscles 1st edition. Hardcover, 2012 January 1. 1600.

Надійшла 02.03.2020

\section{ІНФОРМАЦІЯ ПРО АВТОРА}

Гамалій Володимир Васильович https://orcid.org/0000-0002-8389-0832, gamali@ua.fm Національний університет фізичного виховання і спорту України, 03150, Київ, вул. Фізкультури, 1.

\section{INFORMATION ABOUT THE AUTHOR}

Gamaliy Volodymyr https://orcid.org/0000-0002-8389-0832, gamali@ua.fm National University of Ukraine on Physical Education and Sport, 03150, Kyiv, Fizkul'tury str., 1 